\title{
Reflexão e determinação práticas em Kant
}

\author{
Vinicius de Figueiredo
}

Professor da Universidade Federal do Paraná (UFPR)

Uma versão preliminar da argumentação aqui desenvolvida foi publicada sob o título "Mundo inteligível e analogia na moral de Kant", in: Edmilson Menezes; Marisa Donatelli (orgs.). Modernidade e a idéia da História. Ilhéus: Editora da Universidade Estadual de Santa Cruz, 2003, vol. 1, p. 106-25. 


\section{Reflexão e determinação práticas em Kant}

É comum resumir a experiência moral kantiana à adesão do agente à lei que sua própria razão lhe impõe. $\mathrm{O}$ valor incondicional da autonomia aparece, desse modo, como elemento suficiente para uma doutrina normativa do agir, mesmo sob o risco de tornar o agente que segue a razão alguém alheio à experiência em que se inscreve efetivamente. Contra essa leitura, procura-se mostrar aqui que, para Kant, (i) a determinação da vontade pela razão traz consigo uma reflexão sobre as condições de efetivação da moralidade, assegurando o sentido da perfórmance moral, e que (ii) tal reflexão possui um significado genuinamente especulativo.

Palavras-chave: lei moral, determinação, reflexão, metafísica especial

\section{Practical reflection and determination in Kant}

It is common to reduce the Kantian moral experience to the agent's adhesion to the law that imposes him his proper reason. The unconditional value of the autonomy comes, in this way, as sufficient element to a normative doctrine of action, even though under the risk to become the agent that follows the reason in someone distant from the experience which inscribe himself effectively. Against this reading, it's convenient to show here that, for Kant (i) the will's determination by the reason brings on itself a reflection about the morality's effectively conditions, verifying the moral performance's sense, and which (ii) reflection owns a meaning authentically speculative.

Key words: moral law, determination, reflection, special metaphysics 
São bem conhecidas as palavras com que Kant dá início à Conclusão da Crítica da razão prática: "Duas coisas enchem o ânimo de admiração e veneração sempre novas e crescentes, quanto mais frequentemente e com maior assiduidade delas se ocupa a reflexão: $O$ céu estrelado sobre mim e a lei moral em mim" (KpV, A 288). O que diz essa imagem? O céu estrelado evoca "o imensamente grande", e a "inumerável quantidade de mundos" que ele deixa entrever "aniquila a minha importância como criatura animal"; mas, por esta constatação da completa irrelevância de minha condição sensível, "meu eu invisível", "minha personalidade" são reforçados em seu estatuto noumênico: "a lei moral me descobre uma vida independente da animalidade e mesmo de todo o mundo sensível", estendendo-a "até o infinito" (KpV: V, 162; trad. 183-184). Em suma, o rebaixamento de minha natureza sensível pelo ilimitado é contrabalançada pelo fato de que o infinito é restituído à minha intimidade racional.

Embora o intuito de Kant na Conclusão seja reafirmar a importância da análise na investigação da moralidade, e não retomar os elementos da experiência configurada pela assunção da lei moral, os dois aspectos estão ligados. Afinal, a elucidação filosófica das noções práticas toma-as como significações válidas para os homens - significações, portanto, concebidas e experimentadas por seres dotados de razão e sensibilidade - ainda que eles possam não dispor de inteira clareza acerca delas. Como diz Kant em nota do Prefácio da Crítica da razão prática (KpV, A 14, nota), ninguém ignora o que seja a moralidade, e a filosofia seria de pouco auxílio se a lei moral não estivesse presente em nossa consciência. Sob esse aspecto, é lícito dizer que a investigação prática, embora esteja lon- 
ge de ser uma descrição dos nossos estados de consciência, concerne à psicologia das faculdades do agente moral, que a "Conclusão" apresenta como ser sensível e racional, e, nesta medida, capaz de enfatizar um dos dois polos cuja relação configura a base de sua inserção como agente no mundo. É para essa duplicidade de pontos de vista que Kant chama a atenção, assinalando porém a hierarquia vigente entre eles. Abandonada a si mesma, a prodigalidade da imaginação jamais possibilitaria ao agente entrever a ordem cosmológica no interior da qual ele se determina ao agir. Graças à consideração racional, porém, a ação moral pode ser inscrita em um todo sistemático que lhe confere sentido e orientação.

Visto em escala, esse passo da Conclusão ajuda a vislumbrar a novidade que o idealismo crítico traz para a filosofia prática. Afinal, a infinidade da criação, premissa para a conclusão pascaliana sobre a miséria do homem ${ }^{1}$, é, juntamente com sua antítese, qualificada pela Crítica como ilusão cosmológica da razão dogmática. Mas a solução das antinomias, longe de tornar a razão indiferente à infinidade, ensina que esta é ideia sua, e, nesta medida, apta a um uso legítimo com base nos parâmetros trazidos pela revolução copernicana em filosofia. Emancipada da dependência em relação aos objetos, característica da atitude dogmática, a razão se torna apta a determinar teleologicamente (zweckmässig) a existência do agente que se pauta pela lei moral. Kant passa ao largo da conclusão de Pascal - depreendese daí por que retoma em chave crítica a cosmologia racional. Seu exame figura, desse modo, como condição prévia da caracterização da experiência moral a ser oferecida na Fundamentação da metafísica dos costumes e na Crítica da razão prática. Afinal, a aposta iluminista de que o homem possui na razão uma faculdade capaz não apenas de fornecer as condições requeridas para o discernimento e a ação morais, como, e sobretudo, de oferecer ao agente que determina sua máxima por dever a inteligibilidade dos fins propiciados por essa 
determinação, supõe previamente o credenciamento da razão como sendo, por excelência, "faculdade dos fins", ainda que tais fins não admitam as formulações positivas típicas do conhecimento teórico.

A questão passa a ser, então, como essa condição prévia do uso prático da razão, representada pelo acolhimento crítico das ideias especulativas na primeira Crítica, inflete em um momento positivo na caracterização da experiência moral de que nos dá conta o passo da Conclusão de 1788. Note-se que a apresentação do agente moral como alguém cuja perfórmance reúne a determinação racional da vontade e a doação de sentido que esta implica - duas características que a análise intentada na Crítica da razão prática identificou e circunscreveu - longe de ser uma novidade da Conclusão, insinua-se em outros momentos da obra, como, por exemplo, KpV, A 115 e A 121. Neles, porém, a ênfase recai sobre o binômio que opõe phaenomena e noumena, relegando a segundo plano aquilo que se segue da promoção do agente à condição de inteligência, a saber: o fato de que, com isso (e como não deixa de advertir Kant em um passo cujo assunto é a sublimidade do dever), ele põe sob si "a totalidade completa dos fins" (KpV, A 155) requerida pela lei moral. Podemos explicar essa diferença pelo contexto argumentativo em que se inscrevem essas passagens antecedentes à Conclusão: tanto o dever quanto o respeito, os temas diretamente concernidos, são implicados pela doutrina da liberdade como autonomia, isto é, como lei que o agente dá a si mesmo. Nesse contexto, explorado basicamente ao longo da Analítica Prática, assiste-se a uma formulação que reúne, sob o exame da consciência da lei moral, duas conclusões cuja articulação havia sido apresentada na primeira Crítica. De um lado, a causalidade livre da vontade apela para a espontaneidade do entendimento, apresentada na Analítica da Razão Pura; mas ela só o faz, na medida em que realiza a inflexão da liberdade transcendental, discutida na Dialética especulativa, em liberdade prática. Em contrapartida, a questão do sentido admitido pela vontade determinada pela lei moral aparece expressamente (mas 
não apenas) na Dialética da Razão Prática, quando Kant apresenta e soluciona a antinomia que paira sobre ela.

Sabemos que a via enveredada por Kant para suprimir o conflito aparente entre moralidade e felicidade, núcleo da antinomia prática, leva à reabilitação (com propósitos não teóricos) de duas teses especulativas, a imortalidade da alma e a existência de Deus, sob o título de postulados práticos. Ora, com essa retomada dos temas da metafísica especial no âmbito da filosofia prática, temas que já haviam sido credenciados em sua função regulativa relativa ao conhecimento empírico pela crítica da razão especulativa, Kant apresenta sua alternativa ao diagnóstico pascaliano da experiência moral. Ao contrário do que supôs o autor dos Pensamentos, à razão é não apenas facultado o poder de determinar a vontade - isto é, de ser prática, como mostra a consciência da lei moral. Ela também fornece ao agente que se determina por ela um horizonte de sentido para suas ações, delimitado a partir de princípios especulativos infletidos criticamente no uso prático da razão. Desse modo, nos antípodas do homem pascaliano - refém do amor-próprio e incapaz de cogitar um sentido para a própria existência, resta-lhe, desfeita a impostura da razão, a graça e a aposta -, o agente kantiano confere à própria existência sentido e esperança com base na razão, fornecendo à experiência moral uma alternativa bem mais alentadora do que aquela oriunda da reinterpretação moderna do agostinismo.

Desde muito cedo, porém, a ideia de que o agente, ao determinar moralmente sua vontade, por isso mesmo se inscreve na totalidade de sentido propiciada pela razão, foi relegada a segundo plano, quando não ignorada, pelas avaliações a que se viu submetida a doutrina moral kantiana. Em vez disso, a recuperação prática do mundo inteligível por um ser sensível dotado de razão foi lida quase unicamente como violência que o agente impõe a si mesmo, enquanto ser também dotado de inclinações. E, assumida essa premissa, o debate passou a girar em torno de saber se essa autocoerção é desejável ou não, e mesmo factível ou não, como se aí estivesse fixado de uma vez 
por todas o preço a pagar pelos simpatizantes da autonomia moral kantiana. Descartou-se a interpretação conforme a qual essa autocoerção, embora parte integrante, não dá conta da complexidade da experiência moral kantiana, na medida em que, segundo o autor da filosofia crítica, tomar a razão como fundamento determinante da vontade, ao mesmo tempo em que impõe tal autocoerção, acolhe na reflexão a esperança de realização do sumo bem.

Foi desse modo que Schiller, talvez o pioneiro nessa via interpretativa, enxergou na diferença entre condição natural e destinação racional do homem um abismo cuja superação exigiria o recurso a um terceiro termo, a arte, capaz de mediar a relação entre ser e dever ser, entre matéria e forma (Schiller 33, p. 28). O jovem Schelling retomou o dualismo de perspectivas inaugurado por Kant para caracterizar a finitude como registro no qual toda posição é, ao mesmo tempo, oposição, dotando desse modo a condição mundana da negatividade capaz de restabelecer, do ponto de vista prático, a identidade originária do Eu absoluto (Schelling 34, p. 191). O mesmo compromisso com a síncope kantiana entre o racional e o sensível é afirmado pelos românticos: enquanto Schlegel irá definir a ironia como remédio contra a cisão (Spaltung) metafísica entre o ideal e o efetivo ${ }^{2}$, Novalis irá ver no humor o resultado de "uma livre mistura do condicionado e do incondicionado" (Novalis 25, p. 239).

Não bastassem esses aprofundamentos, a ênfase sobre a estrutura dualista representada pela distinção e mútua referência entre o normativo e o efetivo também merece atenção por ter sido o principal motivo da bem conhecida objeção ao formalismo de Kant. A polaridade entre o efetivo e o normativo exprime-se como imposição absoluta da razão aos sentidos; daí certos leitores de Kant - não sem o apoio de alguns de seus textos - terem concluído que, ao agir, o homem moral põe de lado todas as considerações que poderiam advir da experiência efetiva em que se vê inscrito para conformar-se

2 Cf. J. Ritter \& K. Gründer (edit.). Historisches Wörterbuch der Philosophie, verbete . "Ironie" 
exclusivamente à Moralität, que, calcada na noção de Lei exposta na Analítica da Razão Pura Prática da segunda Crítica, ordena tout-court o que fazer. Com efeito, a moralidade tira seu caráter prescritivo da síncope que a preside: Deus e as criaturas puramente racionais não agem moralmente, pois, para Kant, a moralidade toma sua medida do mesmo contraste que o agente tem de esforçar-se permanentemente por suprimir (cf. GDLG: IV 439; trad. 144). Compreende-se, assim, que o imperativo categórico tenha sido interpretado como expressão de uma moral avessa aos fatos, refém de um preconceito teológico do autor ou até como prova da ingenuidade de Kant frente aos obstáculos que a vida burguesa impunha à virtude - obstáculos com os quais qualquer leitor de Richardson ou Fielding (ambos conhecidos por Kant) no final do século XVIII já deveria estar suficientemente familiarizado.

Não faltam exemplos desse tipo de objeção, de resto compartilhada pela interpretação dualista comum às variantes do pós-kantismo, cujo empenho em introduzir mediações na oposição inaugurada por Kant manifesta o mesmo incômodo frente ao que, na falta de termo melhor, poder-se-ia chamar o irrealismo de sua moral. Com a sátira da boa alma königsbergiana, apresentada por Hegel na Filosofia do Direito, o estigma consagrou-se ao longo do século XX. Horkheimer dá-nos um exemplo:

É devaneio idealista a opinião de que a boa intenção — por mais importante que possa parecer este impulso - seria a única coisa boa, a avaliação da ação apenas pelo que ela intenta e não também pelo que ela significa realmente no respectivo momento histórico. Partindo desse aspecto ideológico do conceito kantiano de moral, um caminho reto leva à moderna mística do sacrifício e da obediência, que fora disso se reporta erroneamente a Kant. ${ }^{3}$

3 Horkheimer 8, p. 67. Tal juízo está longe de ser exclusivo da teoria crítica; em obra relativamente recente, por exemplo, A. Macyntire afirma que "qualquer um educado na 
Tendo em vista tais críticas, não deixa de causar espécie o fato de que a moral do dever tenha sido reabilitada no século XX por parte significativa da interpretação de língua inglesa do kantismo - e isso, a ver de perto, pelos mesmos motivos que conduziram leitores como Horkheimer à objeção de irrealismo. Essa inflexão, cujos motivos de fundo não são discutidos aqui, teve implicações relevantes para a Kantsforschung. Procurando oferecer uma base normativa condizente com as exigências contemporâneas de um pensamento pós-metafísico, buscou-se seccionar o vínculo, existente no texto kantiano, entre o Dever e as ideias de Deus e da imortalidade da alma, as quais, como já observamos, embora sejam neutralizadas na primeira Crítica como objeto de nosso conhecimento teórico, são reabilitadas por Kant tão logo estejamos às voltas com a sistematização do conhecimento empírico (cf. KrV, A 643/B 670 ss.) e, adiante, com a doação de sentido à conduta do agente que se determina pela razão.

A defesa da independência da doutrina da Lei moral diante de toda e qualquer reabilitação prática dos temas da metafísica clássica terminou por revelar-se convergente com a interpretação de acordo com a qual o essencial da ética de Kant está no imperativo categórico - só que, em vez de anunciar o obstáculo representado pelo "formalismo", a ênfase dada à doutrina da obrigação passou a pautar a exegese dos textos, motivada pela busca de um procedimento capaz de responder, sozinho, pela força normativa entrevista nas ações morais. H. J. Paton, por exemplo, afirma que as crenças metafísicas sobre Deus e a imortalidade da alma, que acompanham o postulado do soberano Bem, "não alteram o conteúdo de sua ética e nada acrescentam ao supremo valor da vontade moral ou à natureza obrigante do imperativo categórico" (Paton 26, p. 156 apud Mattos 23, p. 13). L. W. Beck recusa a ideia, expressa por Kant, de que a moralidade tenha de fazer referência às ideias especulativas tratadas na Dialética da razão pura: admiti-lo seria, em última análise, macular a base

noção kantiana de dever desejará, nesta medida, ter sido educado em um conformismo fácil com autoridade" (22, p. 198). 
normativa da ética edificada por Kant com suposições metafísicas pouco afeitas à reabilitação contemporânea do kantismo. ${ }^{4}$ Aprofundando essa corrente, J. Rawls, em sua última obra publicada em vida, chega a dizer que os postulados práticos não passam de uma herança da metafísica leibniziana, desnecessária ao bom andamento da moralidade fundada por Kant. ${ }^{5}$

Acredito que essas duas linhas de interpretação, embora movendose em sentidos opostos, compartilhem de um equívoco comum, representado por duas lacunas recorrentes nas versões que apresentam da posição de Kant. Primeiro, perde-se de vista, em maior ou menor grau, o elemento de articulação que preside a passagem da crítica da razão teórica à crítica da razão prática. Essa articulação, frequentemente examinada tendo em vista a relação, expressa em 1781 e 1787, entre liberdade transcendental e liberdade prática, está longe de esgotar-se nela. Ao contrário: a tese kantiana de que a liberdade prática pressupõe a possibilidade da liberdade transcendental constitui somente a parte mais visível da consideração de conjunto que une as duas primeiras Críticas. Subjaz a essa relação temática outra, mais profunda mas nem por isso menos essencial, representada pelo reordenamento elementar que Kant promove com a passagem da primeira à segunda Crítica. Com efeito, a doutrina dos elementos da Crítica da razão prática segue de perto a exposição da metafísica especial, realizada na Dialética Transcendental da Razão Pura. Com esta diferença decisiva: a liberdade, que lá aparecia no centro da questão cosmológica, tornase o mote da Analítica Prática - deslocamento para o qual a demonstração prévia de que a liberdade transcendental é possível constitui condição necessária, embora não suficiente -, enquanto os temas da psicologia e da teologia permanecem figurando, mas agora a título de postulados práticos, na Dialética de 1788.

4 Beck 2. Para o elogio contemporâneo de Kant na linha mencionada aqui, ver a conclusão de Schneewind 35.

5 Rawls 29, p. 317. Sobre o enraizamento da teoria política de Rawls em Kant, ver Rouanet 31 (à página 105, toca-se na divergência entre eles). 
Não é preciso entrar no mérito das razões desse reordenamento para concluir que, ao tomar como princípio de exposição da investigação prática a tripartição vigente no exame a que submetera o conhecimento racional especulativo, Kant entende haver uma relação relevante entre as ideias especulativas da razão e a filosofia prática, conforme apontávamos no início deste texto, ao referirmonos à Conclusão da Crítica da razão prática. Desatentar disso e insularizar o essencial da moralidade kantiana na Analítica da Razão Prática representa, sob esse ponto de vista, resumir arbitrariamente o significado prático das ideias - sobre o qual Kant é categórico no prefácio à segunda edição da Crítica da razão pura — ao alcance determinante assumido em 1788 pela liberdade como autonomia, ignorando que os pressupostos críticos que tornam possível essa mesma determinação moral da vontade não se encerram com a nova abordagem que a liberdade recebe na Analítica Prática. Caso não se atente a isso, dificilmente ter-se-á na devida conta - e aqui está a segunda lacuna - a articulação interna vigente entre a Analítica e a Dialética práticas. Em suma: deixa-se intocado, como irrelevante ou secundário, o papel que os postulados práticos possuem para a experiência moral correspondente à determinação da vontade pelo imperativo categórico.

Diante desse cenário, tampouco a interpretação de H. Allison (1), profícua sob muitos aspectos, parece oferecer a inteligibilidade merecida pelo ponto em pauta, visto no conjunto admitir que a Analítica da Razão Prática detém prerrogativas quando o assunto é a doutrina da liberdade kantiana. Com efeito, vimos que embora movidas por propósitos antípodas, as interpretações que perfilamos acima, sob dois tipos opostos de leitura de Kant, compartilham em maior ou menor grau o pressuposto de que possamos sem prejuízo resumir sua moral à defesa exclusiva do valor da obrigação, expressa na forma da lei. Em vez de questionar se esse insulamento é realmente lícito, Allison não o problematiza, contentando-se em suprimir a implicação que era retirada dele para a experiência moral 
protagonizada pelo agente kantiano. Mas uma coisa é, confrontando a leitura inaugurada por Schiller, mostrar que a adoção da lei moral como princípio determinante da vontade não necessariamente faz o agente assim determinado se anular como ser sensível dotado de inclinações. Outra, aliás compatível com isso mas bem diferente, é reconhecer que, sem o recurso às ideias especulativas naquilo que acarretam para a prática, o agente moral é incapaz de dotar de sentido sua existência enquanto personalidade noumênica. Ora, conforme já aponta a articulação interna existente entre Analítica e Dialética na Crítica da razão pura, Kant vincula a produção de sentido das determinações operadas por nós com a ideia da totalidade sistemática. A esse vínculo, por sua vez é imprescindível a retomada, em chave crítica, do conjunto dos temas da metafísica especial. ${ }^{6} \mathrm{Se}$, como é de se esperar, a imbricação entre os momentos determinante e reflexionante da razão, constatada em seu uso especulativo, também se verifica no seu uso prático, então, para dar conta da complexidade da experiência moral kantiana, parece ser imprescindível dar um passo para fora da Analítica Prática, seja reavendo sua referência de origem à Dialética especulativa, seja acompanhando sua solidariedade doutrinal interna com a Dialética da Razão Prática. Frente a essa exigência relatica à ordem e ao reordenamento elementar da doutrina kantiana na segunda Crítica, não basta dourar a pílula do dever, assinalando que tomá-lo por princípio não acarreta negar-se como agente que considera, juntamente com a lei, as próprias inclinações, como faz Allison, nem tampouco, como propõe R. Louden (20) (em um livro muito instigante, em que se alinha à orientação geral de Allison), recordar que a circunscrição do dever é acompanhada da consideração antropológica da situação do homem como agente inscrito em uma economia afetiva e passional - irredutível, em toda a sua complexidade, aos imperativos da razão pura. Pois a

6 Cf. Leopoldo e Silva 19. Procurei assinalar a importância dessa operação de totalização para a epistemologia kantiana em um estudo introdutório à Crítica da razão pura (Figueiredo 3). 
antropologia kantiana representa, ao lado da história e da religião, menos a contrapartida impura e positiva da ética do que o desdobramento da articulação entre determinação e reflexão racionais no âmbito prático. Daí Kant cuidar de caracterizá-la como "pragmática" (Kant 9, p. 21): ela não admite um saber positivo, precisamente por ter a função de conferir à positividade prática seu horizonte de sentido mediante a reflexão - o que outra vez remete ao exame prévio do papel que as ideias especulativas possuem junto à caracterização da experiência moral do agente.

A despeito do prestígio da leitura insular da moralidade kantiana - da qual, como apenas indicamos, o recente trabalho de Allison parece representar a versão mais sofisticada -, não faltam exemplos de abordagens que, enveredando por outra direção, comentam a filosofia prática kantiana dando especial atenção ao teor sistemático da filosofia preparada pela crítica e às articulações daí advindas. Se examinarmos os estudos sobre Kant no Brasil, é notável constatar a existência de uma linha de força que delineia a alternativa que temos em vista. Penso naquelas interpretações que, diferenças à parte, reconhecem de que, em Kant, há uma relação positiva entre determinação e reflexão racionais, indispensável para a elucidação dos elementos da doutrina possibilitada pela filosofia transcendental. A relação começaria pelo livro de G. Lebrun, Kant et la fin de la métaphysique (1970), que, embora publicado primeiro na França, marcou diretamente a interpretação de Kant no Brasil. Lebrun detém-se em examinar a passagem da primeira à terceira Crítica. Para fazê-lo, demonstra, porém, que a interdição do dogmatismo não teve por objetivo dar as costas à metafísica especulativa examinada na Dialética da Razão Pura. Mostra-nos, ao contrário, que ali onde Kant anuncia o fim do trabalho crítico — isto é, na Crítica do Juízo (1790) -, o reencontramos às voltas com a reabsorção e transposição dos temas da metafísica especial para os termos da antropologia nascente (Lebrun 18, p. 687 e ss). Conforme Lebrun, o território em que irá se alogar o homem moderno é circunscrito a partir da reinterpretação a que Kant submete as significações teológicas para 
as quais, até a Crítica, se buscava uma formulação teórico-dogmática. De seu lado, J. A. Giannotti, em um ensaio publicado originalmente em 1979 e que concerne mais diretamente à filosofia prática, também se atém às consequências da relação entre determinação e reflexão apresentadas inicialmente na Crítica da razão pura apontando que a finalidade operante na exigência de totalidade que subjaz à determinação de objetos da experiência reaparece ali onde Kant examina as condições que possibilitam a "objetividade prática"?

Três outros estudos importantes discutem o horizonte de realização do núcleo normativo estabelecido sobre a doutrina da liberdade, assumindo que a reinterpretação da metafísica especial possui nisso algum papel. F. H. Herrero enuncia o tema de sua investigação — como a razão realiza-se na história — referindo-se de pronto à doutrina do sumo bem, e conclui seu livro sublinhando que a filosofia da história de Kant representa o plano em que a totalidade e o incondicionado, sediados na razão, são realizados. Já Ricardo R. Terra principia a abordagem dos conceitos políticos kantianos recordando que a idealidade prática destes, apresentada por Kant no início da Dialética Transcendental, exige a articulação entre as noções jurídicas e a história na qual podem realizarse. M. A. Zingano, por sua vez, diferencia espontaneidade do entendimento e espontaneidade da razão mostrando que somente nesta última a atividade põe livremente seu objeto, o que implica fornecer à vontade determinada pela lei moral um horizonte de sentido graças ao qual o agente se inscreve em uma comunidade de seres racionais autônomos (Herrero 7, p. 31 e 185; Terra 36; Zingano 38). Nesses três estudos, por-

7 O enlace entre determinação e reflexão especulativa é formulado claramente por Giannotti, pois, como diz, embora a liberdade (consciência da lei moral) seja o princípio supremo da moralidade, a razão "necessita sair de seu movimento enquanto cadeia de raciocínios práticos, postular o incondicionado como um Deus existente e, por isso, criador de todos os seres. (...) Um dever totalmente cortado de suas condições de existência abriria uma cesura na natureza criada, o que contraria nosso conceito prático de um Deus criador" (Giannotti 6, p. 125-6). Noutro texto, publicado primeiramente em 1979, G. Lebrun aborda diretamente a relação entre moralidade e história com o exame da noção de "reino dos fins", convergindo com J. A. Giannotti quanto à função essencial da teleologia na filosofia prática kantiana (Lebrun 17, p. 75-101). 
tanto, encontram-se, em graus diferentes, elementos para reforçar a tese da importância do papel que a reflexão, como operação racional de totalização das particularidades, joga no interior da caracterização do agir. Além deles, constata-se o aparecimento de trabalhos que, convergindo nessa direção, têm aprofundado o debate sobre a relevância da reflexão em Kant, quer para a religião, quer para a política, quer para a moralidade stricto senso e mesmo para a trajetória que conduz do período pré-crítico à Crítica da razão pura. ${ }^{8}$

Dispomos assim, de boas razões para suspeitar que talvez possamos evitar a alternativa entre combater o formalismo moral, recorrendo ao antídoto representado pela mediação sociológica ou estética; e, ao contrário, ater-se exclusivamente ao imperativo categórico resumindo a um procedimento toda a verdade da filosofia prática de Kant, a fim de reaver sua inteligibilidade. Em vez disso, é lícito sustentar que sua moral representa uma perspectiva inteligível sobre o âmbito efetivo, graças à qual o agente pode reunir à consciência da lei a faculdade de orientar-se, isto é, de compreender seus atos como voltados a um todo diverso do mundo sensível, e unicamente por referência ao qual sua conduta adquire sentido. Mas tal doação de sentido requer a reinterpretação crítica da metafísica especial, porque convoca as ideias especulativas e a totalização racional que elas implicam, a fim de conferir à determinação moral do agir um horizonte compreensivo, para o que apenas a obediência à lei não basta. Antes, é a própria limitação da vontade pela lei da razão o que implica remissão à totalidade — esta, através dessa inflexão prática, se torna realizável como história na qual a humanidade pode cumprir sua destinação.

8 Cf. Menezes 24; Mattos 23; Pimenta 28; Lousado 21 e Santos 32, além do já citado artigo de Leopoldo e Silva (19). Essa relação, obviamente, não possui qualquer intuito exaustivo. Convém porém mencionar, como variante do tema em pauta, o estudo de D. T. Peres (27), assim como trabalhos mais recentes de R. Terra 36 (p. 109-119). Ambos destacam, como função principal da reflexão, que ela possibilita medir a distância entre a inteligibilidade de nossas noções racionais e sua inscrição efetiva, o que é diverso de enfatizar que nela transcorre a passagem racional do determinado ao incondicionado. 
Logo, ao contrário do que pretendem as interpretações que tendem a insular o principal da doutrina de Kant na Analítica prática, e inscrevendo-nos nos estudos feitos entre nós elencados há pouco, defendemos (i) haver uma articulação necessária entre reflexão e metafísica especial, na Crítica da razão pura; (ii) que essa articulação ressurge na relação existente entre a determinação racional da ação, apresentada na Analítica da Razão Prática, e a inscrição da conduta assim determinada em uma totalidade racional, como apresentada na Dialética da Razão Prática. Sem atentar a essa articulação entre os momentos analítico e dialético, não haveria como outorgar um sentido compreensivo à ação motivada por obediência à lei moral, o que implicaria fazer da doutrina kantiana uma moral do dever, perdendo de vista que ela também cuida de apresentar a esse mesmo dever o seu sentido.

Mencionamos, acima, que a estrutura da segunda Crítica toma seu princípio de divisão elementar da Dialética especulativa. Somam-se a isso mais dois motivos, concernindo igualmente à relação sistemática concebida por Kant entre a Crítica da razão pura e a Crítica da razão prática, que reforçam essa hipótese de leitura, antes mesmo de entrar em uma análise aprofundada da doutrina do sumo bem, que figura na Dialética Prática.

1. A unidade da razão. A interpretação do dualismo moral a partir da extensão prática de que são capazes as significações especulativas depende, preliminarmente, da convergência temática entre a crítica do conhecimento especulativo e a doutrina da razão prática. É digno de nota, a esse respeito, o que Kant tem a dizer sobre a unidade da razão, na Segunda Crítica:

Se a razão pura pode por si mesma ser prática, e de fato o é, como o demonstra a consciência da lei moral, é no entanto sempre apenas uma 
e mesma razão que, quer seja do ponto de vista teórico ou prático, julga segundo princípios a priori; e é evidente que, embora do primeiro ponto de vista o seu poder não seja suficiente para estabelecer peremptoriamente certas proposições que, contudo, não estão precisamente em contradição com ela, deve, logo que essas proposições estão indissoluvelmente ligadas ao interesse prático da razão pura, admiti-las, sem dúvida como uma oferta a ela estranha, que não proveio de seu solo mas, no entanto, bastante certificada, e procurar compará-las e conectá-las com tudo que tem em seu poder, enquanto razão especulativa. (KpV: V 121; trad. 140)

Essas proposições que a razão é incapaz de estabelecer de modo positivo com intuito teórico são, justamente, aquelas relativas à imortalidade da alma e à existência de Deus, discutidas na Dialética da Primeira Crítica. Nessa passagem, Kant diz expressamente que essas ideias estão indissoluvelmente ligadas ao interesse prático da razão, a qual lhes investe de um intuito moral, por ocasião da determinação pura da vontade. Ou seja: determinar moralmente a vontade e pensar com intuito prático os temas da Dialética da Razão Pura aparecem, aqui, como sendo uma única e mesma coisa. Contra, portanto, as interpretações que procuram insular toda a complexidade da experiência moral na obediência à lei apresentada na Analítica da segunda Crítica, convém recordar a ideia de arquitetônica e, com ela, buscar reaver a visão de conjunto que informa o programa kantiano. A afirmação da unidade da razão faz da filosofia crítica um sistema de passagens entre os elementos que ela organiza como doutrina. Essas passagens não são aleatórias: o primado da razão prática, adverte-nos Kant, pressupõe que sua união com a razão especulativa "não seja, claro está, contingente e arbitrária, mas fundada a priori na própria razão, por conseguinte, necessária" (KpV:V 121; trad. p. 140).

2. Determinação prática do incondicionado. O que, porém, significa pensar com intuito prático os temas da Dialética especulativa? No 
Prefácio à segunda edição da Crítica da razão pura, em uma passagem na qual discorre sobre as implicações práticas da interdição da ontologia dogmática, Kant dá a pista:

(...) depois de ter sido negado à razão especulativa qualquer avanço no campo do suprassensível, resta-nos considerar se não existem no conhecimento prático dados que nos permitam determinar o conceito transcendente do incondicionado e assim, de acordo com o desejo da metafísica, ultrapassar os limites de toda a experiência possível por meio do nosso conhecimento a priori que só é possível para propósitos práticos. (KrV: B XIX, XXI, grifo nosso)

O interesse desta passagem reside em que, nela, o problema da determinação moral do arbítrio se vê atrelado à problemática crítica do limite. ${ }^{9}$ Com efeito, um arbítrio determinado moralmente requer a determinação do "conceito transcendente do incondicionado". Assim, o mesmo incondicionado que, em função de sua indeterminação face ao conhecimento da natureza, foi neutralizado pela primeira Crítica como objeto de um saber positivo, se torna, graças ao intuito moral da razão, determinável praticamente. Pensar com intuito prático os temas da Dialética da Razão Pura, conclui-se, equivale a determinar o conceito transcendente do incondicionado. É isso que, de resto, nos diz a metáfora da segunda Crítica, citada de início: a ilimitação do céu estrelado inflete na determinação prática do infinito. Daí por que é unilateral encerrar a verdade da moralidade kantiana na violência que a representação da lei faz aos sentidos; ao contrário, a mesma "experiência" instituída pela determinação livre da vontade reabre o infinito como tema do pensamento em regime prático.

9 Ver Mattos 23, que repassa com grande interesse as interpretações clássicas acerca do significado das ideias para a moralidade kantiana, salientando a importância assumida aí pelo problema crítico do limite. 
Entretanto, assinalar que a moralidade constitui o horizonte de determinação do conceito transcendente do incondicionado, e que, por isso, é de se esperar que o intuito sistemático da razão, meramente regulativo no que respeita ao conhecimento da natureza ( $\mathrm{KrV}$ : A 645, B 673), se torne determinável mediante a obediência à Lei coisa que, de resto, Kant dá a entender desde o Cânone da Crítica da razão pura $^{10}$ - não implica questionar a lei moral como condição suprema da moralidade. Pelo contrário: não nos parece haver contradição em afirmar o estatuto principial da lei moral e, ao mesmo tempo, assinalar que a determinação moral do arbítrio possibilita ao agente inscrever sua ação em uma conexão sistemática do agir em geral. Vale lembrar, a este propósito, que, na Fundamentação da metafísica dos costumes, Kant apresenta como um dever efetuar uma "ligação sistemática de seres racionais por meio de leis objetivas comuns", leis que, por terem em vista "a relação destes seres uns com os outros como fins e meios", instituem "um reino dos fins" (GDLG: IV 433; trad. 139). Isso significa que determinar-me moralmente será o mesmo que relacionar minha conduta com a comunidade representada pelo conjunto dos homens tomados como seres racionais. Em suma: o que constitui a moralidade da ação será, precisamente, sua referência racional à humanidade, possibilitada pela reabilitação prática da noção especulativa de sistema.

Assim, o reino dos fins institui como condição da moralidade da minha ação a sua projeção em uma comunidade inteligível, na qual todo ser racional é tomado como fim em si mesmo. Com efeito, uma nota da Fundamentação atesta que a noção de reino dos fins reabilita - com intuito prático — o que Kant discutira na Dialética

10 “Com efeito, já que a razão ordena que tais ações [em conformidade com os preceitos morais] devem ocorrer, elas também têm de poder ocorrer e, por conseguinte, tem que ser possível um tipo particular de unidade sistemática, a saber, a moral" (KrV: A 807, B 835). "A moralidade em si mesma perfaz um sistema" (KrV: A 811, B 839). 
da primeira Crítica sob o título da ideia teológica. ${ }^{11}$ Mas, enquanto a Dialética especulativa havia se contentado em definir a ideia teológica como ideal mediante o qual a razão "pensa um objeto que deve ser completamente determinável segundo princípios, se bem que na experiência faltem as condições suficientes para tanto e que o próprio conceito seja, portanto, transcendente" (KrV: A 571, B 599), a ação moral torna possível "um mundo de seres racionais (mundus intelligibilis) como reino dos fins, e isso graças à própria legislação de todas as pessoas como membros dele" (GDLG: IV 438; trad. 142). Evidentemente, esse ganho de determinação obtido para a noção especulativa de sistema não contraria as cláusulas proibitivas que a crítica impõe ao conhecimento do suprassensível. Ocorre apenas que, ao agir moralmente, inscrevo, graças à projeção possibilitada pela noção de sistema, minha vontade em uma "esfera totalmente diversa da [esfera] empírica" (KpV: V 34; trad. 46). O que, de resto, condiz com a doutrina do imperativo categórico, cuja formulação obriga-nos a fazer da humanidade jamais simplesmente o meio, e sempre o fim de nossa ação (GDLG: IV 429, trad. 135). Sem a recuperação prática da ideia especulativa de sistema, não haveria como ligar a obrigação moral ao que Kant designa o "princípio dos outros homens [Prinzip anderer Menschen]" (GDLG: IV 430; trad. 136).

Se, na Analítica Prática, Kant exclui toda referência objetiva material na determinação moral da vontade pela razão, assegurando assim que a racionalidade prática não consiste no cálculo entre meios e fins. Contudo, isso todavia não significa que, ao determinar a vontade pela simples forma da lei, a razão não imponha ao agente um objeto próprio, por referência ao qual o agente situa sua ação em um horizonte sistemático. Vimos como o elemento sistemático ligado à reflexão subjaz ao "reino

11 "A teologia considera a natureza como um reino dos fins; a moral considera um possível reino dos fins como um reino da natureza. Acolá o reino dos fins é uma ideia teórica para explicar o que existe. Aqui é uma ideia prática para realizar o que não existe mas que pode tornar-se real pelas nossas ações ou omissões, e isso exatamente em conformidade com esta ideia" (GDLG: V 436; trad. 141). 
dos fins" da Fundamentação da metafísica dos costumes. Porém, como é sabido, será na Dialética Prática, assim como sucedera na Dialética da primeira Crítica em relação à razão especulativa, que Kant irá examinar pormenorizadamente a legitimidade da busca do incondicionado para todo condicionado (cf. KpV, A 194). Daí por que, nela, a retomada das ideias especulativas em regime prático possui um desenlace explícito: "Deus e uma vida futura são duas pressuposições inseparáveis, segundo princípios da razão pura, da obrigatoriedade que exatamente a mesma razão nos impõe" (KrV: A 811, B 839). Kant, chamando a atenção para "a ordem dos conceitos da determinação da vontade", adverte que a lei moral está incluída no conceito de soberano bem, o qual, nesta medida, é não só objeto, mas "seu conceito e a representação de sua existência possível mediante a nossa razão prática constituem ao mesmo tempo o princípio determinante da vontade pura" (KpV:V 109-110; trad. 128). Se, como diz o passo da Conclusão da Segunda Crítica citado inicialmente, a admissão da extensão indeterminada do universo em que nos encontramos, embora nos leve a imaginar "mundos sobre mundos" e “tempos ilimitados" (KpV, A 289), não implica negar à razão sua capacidade compreensiva, graças à qual o agente moral "penetra o infinito" (KpV, A 290), isso se deve a que, também aqui, a razão realiza uma totalização das condições que confere a suas próprias determinações o sentido que estas exigem, mas não podem obter sem recorrer à ideia de sistema. No uso prático da razão, essa totalização promove o enlace entre moral e religião, além de esboçar "o espaço da história universal", sem, por isso, ferir o princípio da autonomia nem questionar o estatuto da lei moral como condição suprema do sumo bem. Ao contrário: é a articulação entre a lei moral e os postulados práticos o que possibilita ao agente que determinou sua vontade pela lei moral acolher um sentido para essa determinação.

A despeito de a Dialética Transcendental da Razão Pura ter mostrado não ser lícita qualquer psicologia, cosmologia ou teologia racionais, dispomos, pela a referência do agir à ideia de sistema, de um ponto a partir do qual operam limitações que introduzem sentido no 
julgamento e na ação morais. A possibilidade da determinação da vontade pela razão depende, em conformidade com isso, da extensão prática da razão e da totalidade de sentido que ela proporciona ao agente, possibilitando-lhe situar-se, como inteligência que é, no âmbito dos fenômenos em que, feitas as contas, também se vê inscrito. Foi sobre esse vínculo entre obrigação e faculdade de pensar que se procurou insistir aqui. Embora movidas por propósitos antipódicos, as interpretações perfiladas de início sob dois tipos opostos de leitura de Kant compartilham em maior ou menor grau o pressuposto de que se possa, sem prejuízo, resumir sua moral à defesa exclusiva do valor da obrigação, expressa na forma da lei. Sob essa perspectiva, para o bem ou para o mal deveríamos insular o essencial da moralidade kantiana à Analítica da Crítica da razão prática.

Caso, porém, transpuséssemos a premissa insular para a experiência moral delineada por Kant, ignorando o benefício que a determinação racional da vontade retira da referência às ideias especulativas em regime prático, o constrangimento que o imperativo produz sobre nossa natureza patológica seria tal que o agente, esmagado sob o peso da razão, adquiriria feições trágicas; seu compromisso com o céu inteligível o tornaria refém de um verso em que Drummond, nada iluminista, conclui que "o mundo não vale o mundo". Por certo, a lei moral faz violência à sensibilidade, na medida em que toma por seu princípio a razão, alheia às inclinações que caracterizam o âmbito sensível em que se encontra inscrito o agente. Contudo, não há por que crer que o avesso da condição sensível corresponda à experiência inarticulada do incondicionado ${ }^{12}$, nem tampouco que a admiração e veneração que invadem o ânimo do homem moral privem de juízo sua inscrição no mundo, como se ele fosse alguém incapaz de julgar ao agir precisamente por pautar seu discernimento e sua conduta por princípios morais. Muito rapidamente o dualismo de perspectivas kantiano foi resumido à alternativa entre dois mundos excludentes - como se, ao pressentir

12 Nisto, aliás, reside a objeção de Kant ao salto mortale de F. Jacobi. Cf. Figueiredo 5, p. 87-108. 
a proximidade do absoluto, só restasse ao homem "a escolha pânica entre o prazer sensual e a paz da alma"13 — como se, enfim, o cumprimento da lei equivalesse ao sacrifício no altar da razão, tal como objeta Horkheimer e, feitas as contas, parecem estar dispostos a aceitar Paton e Beck. Mas se - como argumenta Allison - a experiência moral kantiana admite o convívio entre inclinações e dever, isso se deve justamente ao fato de que o limite que a consciência da lei moral impõe à dimensão patológica do homem seja por sua vez refletido pela razão, que, totalizando a determinação autoimposta pelo agente, proporciona à sua conduta um horizonte de realização em que moralidade $\mathrm{e}$ felicidade poderão estar reunidas. A limitação racional da felicidade como soma de inclinações, exigida pela lei moral, é, assim, objeto de uma operação de segunda ordem, igualmente racional, que confere sentido a essa determinação por meio da expectativa da reconciliação futura entre moralidade e felicidade (KrV: A 809, B 837). Isso, porém, requer que "um pensar determinado do suprassensível" (KpV: V 141; trad. 160) seja possibilitado pelo recurso à analogia, disponibilizando ao agente moral uma medida do que pode esperar de sua ação.

Vislumbra-se, então, já na caracterização da experiência moral, o horizonte da filosofia da história, ao qual se vincula, pela noção de sistema, a moralidade de Kant. Apto a cifrar o suprassensível neste ou naquele acontecimento, o agente moral poderá reconhecer o desenvolvimento progressivo, "embora lento", das disposições originais da espécie (Kant 13, p. 9), investindo de significação o mundus intelligibilis em que se vê inscrito pela obediência à lei. ${ }^{14}$ Por sua vez, o fato de que a moral do dever seja assim amparada pela perspectiva teleológica, proveito que a crítica tira da ideia clássica de sistema, isenta a argumentação kantiana de toda objeção de extemporaneidade - motivada que é, replicaria

13 Schiller, "O ideal e a vida" (na tradução de Rubens Torres Filho).

14 O imperativo ordena que cada ser racional aja "como se fosse sempre, pelas suas máximas, um membro legislador no reino universal dos fins" (GDLG: IV 438; trad. 142). Em idêntico sentido, Kant afirmara, na primeira Crítica, que a razão nos constrange a "nos representarmos como pertencentes a um tal mundo [moral]” (KrV: A 811, B 839). 
Kant, pela incompreensão acerca do processo por meio do qual a razão vai impingindo sua marca na efetividade. Não é essa mesma intuição que Hegel irá retomar quando, à beira da ruptura com Kant, proclamar a reciprocidade entre o real e o racional? Essa linha de continuidade, ainda que comporte diferenças significativas, é exata: o idealismo absoluto representa o aprofundamento do idealismo crítico. Se, já aos olhos de Kant, os acontecimentos não podem desmentir por si mesmos a totalidade de sentido possibilitada pela perspectiva racional, é porque a experiência mundana em que se inscreve o agente, longe de dispor de um significado alheio à razão, é toda ela balizada pela referência às ideias especulativas. Daí por que a eventual deformidade do mundo efetivo, em vez de conduzir o agente kantiano à resignação, só faz promover seu esforço na direção do aperfeiçoamento moral da espécie. Afinal, a determinação incondicional do arbítrio é o que descortina o mundo moral como uma consequência que requer sua conduta racional no mundo sensível, mesmo que tal mundo inteligível seja somente "um mundo futuro para nós" (KrV: A 811, B 839). Operando quer como princípio determinante do agir, quer como princípio de sistematização da ação assim determinada, as ideias oriundas da metafísica especulativa revelam-se, em todo caso, decisivas para a moral kantiana. Por meio da crítica, a totalidade incondicionada do absoluto, inalcançável sob o intuito teórico, se mostra realizável praticamente.

\section{Referências bibliográficas}

1. Allison, H. Kant's Theory of Freedom. Cambridge: Cambridge University Press, 1995.

2. Beck, L. W. A Commentary on Kant's Critique of Pratical Reason. Chicago: The Univ. of Chicago Press, 1960.

3. Figueiredo, V. Kant \& Crítica da razão pura. Rio de Janeiro: Zahar, 2005.

4. __ "Mundo inteligível e analogia na moral de Kant” In: E. Menezes, M. DoNATELLI (orgs.). Modernidade e a idéia da História. Ilhéus: Editora da Universidade Estadual de Santa Cruz, 2003, p. 106-125. 
5. ___ "O vórtice Jacobi” In: O que nos faz pensar. Rio de Janeiro: PUC-Rio, 2005, vol. 19, p. 87-108.

6. Giannotti, J. A. "Kant e espaço de uma história universal” In: I., Kant. Idéia de uma história universal de um ponto de vista cosmopolita. Org. R. R. Terra. São Paulo: Martins Fontes, 1984, p. 103-150.

7. Herrero, F. J. Religião e história em Kant. São Paulo: Loyola, 1991

8. Horkheimer, M. “Materialismo e moral”. In: Teoria crítica I. Trad. H. Cohn. São Paulo: Perspectiva, 1990

9. Kant, I. Antropologia de um ponto de vista pragmático. Trad. C. Martins. São Paulo: Iluminuras, 2006

10. __ Crítica da razão prática. Trad. V. Rohden. São Paulo: Martins Fontes, 2002

11. __ Crítica da razão pura. Trad. V. Rohden e U. B. Moosburger. São Paulo: Nova Cultural.

12. ___ Fundamentação da metafísicas dos costumes. Trad. P. Quintela. In: Os pensadores. São Paulo: Abril Cultural, 1972.

13. __. Idéia de uma histórias universal de um ponto de vista cosmopolita. Trad. R. Terra e R. Naves. São Paulo: Brasiliense, 1984.

14. _. Kants Werke. Ed. Königlich Preussischen Akademie der Wissenschaften, Berlin, Georg Reimer. <Akademie Text-Ausgabe, Berlin, Walter de Gruyter \& Co, 1902 em diante $>$.

15.___. Observações sobre o sentimento do belo e do sublime. Trad. V. de Figueiredo. 2. ed. Campinas: Papirus, 2000.

16. KrÜger, G. Philosophie und Moral in der kantischen Kritik. Tübingen: P. Siebeck, 1931.

17. Lebrun, G. "Uma escatologia para a moral”. In: KANT, I. Idéia de uma história universal de um ponto de vista cosmopolita. Org. de Ricardo Terra. São Paulo: Brasiliense, 1984, p. 75-101.

18._. Kant e o fim da metafísica. Trad. Carlos A. R. de Moura. São Paulo: Martins Fontes, 1993.

19. Leopoldo E Silva, F. "Dialética e experiência”, In: Dois Pontos - Kant, 2/2, 2005, p. 97-112.

20. Louden, R. B. Kant's Impure Ethics - From Rational Beings to Human Beings. Nova York/Oxford: Oxford University Press, 2000.

21. Lousado, G. 'Non est' não é 'est non': phaenomenon e noumenon na Crítica da razão pura. Tese (Doutorado) — UFRGS: Porto Alegre, 2003. 
22. Macintyre, A. A short History of Ethics. 2. ed. Notre Dame: Univ. of Notre Dame Press, 1988.

23. Mattos, F. C. Conhecimento prático e metafísica especulativa em Kant. Dissertação (Mestrado) — Universidade de São Paulo, São Paulo, 2001.

24. Menezes, E. História e esperança em Kant. São Cristóvão: Editora UFSE, 2000.

25. Novalis. Werke, Tagebücher und Briefe. Ed. H-J. Mähl \& R. Samuel. Darmstadt: Wissenschaft Buchgesellschaft, 1999.

26. Paton, H. J. The categorical imperative. A Study in Kant's Moral Philosophy. Philadelphia: University of Pennsylvania Press, 1971.

27. Peres, D. T. Metafísica e política. Salvador/São Paulo: EdUFBA/Unesp, 2004.

28. Pimenta, P. P. Reflexão e moral em Kant. Rio de Janeiro: Azougue, 2004.

29. Rawls, J. Lectures on the History of Moral Philosophy. Cambridge: Harvard Press, 2000.

30. Ritter, J. \& GrÜnder, K (edit.). Historisches Wörterbuch der Philosophie. Darmstadt: Wissenschaftliche Buchgesellschaft, 1998.

31. Rouanet, L. P. Rawls e o enigma da justiça. São Paulo: Unimarco, 2002.

32. Santos, P. R. L. Ensaios sobre o problema antinômico na filosofia kantiana. Tese (Doutoramento) — Universidade de São Paulo, São Paulo, 2004.

33. Schiller, F. Educação estética do homem. Trad. R. Schwarz e M. Suzuki. São Paulo: Iluminuras, 1995.

34. Schelling, F. Vom Ich. In: Sämtliche Werke, vol. I. Beck, 1957

35. Schneewind, J. B. The Invention of Autonomy. Cambridge: Cambridge Univ. Press, 1998.

36. Terra, R. R. “Notas sobre o conceito de 'passagem' (Übergang) no pensamento kantiano”. In: PEREZ, D. O. (org.)Kant no Brasil. São Paulo: Escuta, 2005, p. 109-119.

37 __ A política tensa — Idéia e realidade na filosofia da história de Kant. São Paulo: Iluminuras, 1995.

38. Zingano, M. Razão e história em Kant. São Paulo: Brasiliense, 1989. 